\title{
Sedimentary stratigraphy of Lake Chalco (Central Mexico) dur- ing its formative stages
}

Cite this article as: Rodrigo Martínez-Abarca, Beatriz Ortega-Guerrero, Socorro LozanoGarcía, Margarita Caballero, Blas Valero-Garcés, David McGee, Erik T. Brown, Mona Stockhecke and Alastair G. E. Hodgetts, Sedimentary stratigraphy of Lake Chalco (Central Mexico) during its formative stages, International Journal of Earth Sciences https://doi.org/10.1007/s00531-020-01964-z

This Author Accepted Manuscript is a PDF file of an unedited peer-reviewed manuscript that has been accepted for publication but has not been copyedited or corrected. The official version of record that is published in the journal is kept up to date and so may therefore differ from this version.

Terms of use and reuse: academic research for non-commercial purposes, see here for full terms. https://www.springer.com/aam-terms-v1 
1 Sedimentary stratigraphy of Lake Chalco (Central Mexico) during its formative stages

2 Rodrigo Martínez-Abarca ${ }^{1 *}$, Beatriz Ortega-Guerrero ${ }^{2}$, Socorro Lozano-García ${ }^{3}$,

3 Margarita Caballero ${ }^{2}$, Blas Valero-Garcés ${ }^{4}$, David McGee ${ }^{5}$, Erik T. Brown ${ }^{6}$, Mona

$4 \quad$ Stockhecke $^{6}$, Alastair G.E. Hodgetts ${ }^{7}$

$5 \quad{ }^{1}$ Posgrado en Ciencias de la Tierra, Universidad Nacional Autónoma de México, Mexico

6 City, CP. 04510, Mexico.

7 2 Instituto de Geofísica, Universidad Nacional Autónoma de México, Mexico City, CP. 804510 , Mexico.

$9{ }^{3}$ Instituto de Geología, Universidad Nacional Autónoma de México, Mexico City, CP. 04510, 10 Mexico.

$11{ }^{4}$ Instituto Pirenaico de Ecología - CSIC, Apdo 13034, E-50080 Zaragoza, Spain.

$12{ }^{5}$ Massachusetts Institute of Technology, Department of Earth, Atmospheric and Planetary 13 Sciences, 02139 Cambridge, MA, E.U.

$14{ }^{6}$ Large Lakes Observatory \& Dept. of Earth and Environmental Sciences, University of 15 Minnesota Duluth, Duluth, MN 55812, USA

$16{ }^{7}$ School of Geography, Earth and Environmental Sciences, University of Birmingham, 17 Edgbaston, Birmingham, B15 2TT, United Kingdom

18 Corresponding author: bortega@igeofisica.unam.mx

19 Short Title - Stratigraphy of deep deposits in Lake Chalco 


\section{Abstract}

Lake Chalco lies south of the Basin of Mexico and has been the subject of studies related to Late Quaternary climate variability. In 2016, the International Continental Scientific Drilling Program "MexiDrill Project" recovered a 520-m sediment record from Lake Chalco. Magnetic susceptibility measurements revealed substantial changes in sediment physical properties between 343 and $285 \mathrm{~m}$ depth, suggesting changes in composition associated with fluctuations in the depositional environment. We targeted sediments in the $343-285 \mathrm{~m}$ interval for high-resolution facies analysis, to develop a model of Lake Chalco formation. We identified three facies associations, using sediment composition, texture, mineralogy and micro-morphological characteristics: 1) Detrital facies, consisting of laminated silt, massive sand, stratified silty sand, clast-supported gravel and matrix-supported gravel; 2) Biogenic facies, which include diatom ooze and bivalve coquina; and 3) Volcaniclastic facies, represented by clast-supported pumice deposits. We propose that formation of Lake Chalco occurred in four stages, which we identified by changes in sediment characteristics. The first stage was an alluvial delta environment, in which debris and hyper-concentrated flows were the main sediment transport agents. The second was characterized by turbulent flows in a fluvial deltaic environment, which alternated with laminar flows associated with floodplains. The third stage was a time of fluvio-lacustrine transition in the basin, with formation of the previously identified Paleo-Chalco-I Lake, in response to wet conditions. During the fourth stage, a deep eutrophic lake formed (Paleo-Chalco-II), with an origin that appears to have been related to regional volcanism. Our working age-depth model indicates establishment of the lake at ca. $400 \pm 46 \mathrm{ka}$. This paper presents the only available record of the transition from alluvial to lacustrine sedimentation of Lake Chalco. Our results allow us to establish 1) how 
the lake was formed and what the phases of its development were, 2) how a major volcanic event altered and transformed the lacustrine sedimentation, and 3) which climatic conditions dominated during the lake formation. The age for the onset of the lacustrine sedimentation in Chalco is for the first time constrained to around $400 \mathrm{ka}$. This enables to expand our knowledge of the climate for a time for which there is no information from terrestrial records of tropical North America.

Keywords: MexiDrill Chalco, Basin of Mexico, Lake Formation, Facies analysis, Fluviallacustrine system, volcanism and lakes.

\section{INTRODUCTION}

Lake Chalco (Central Mexico) occupies the south-eastern part of the Basin of Mexico, where Mexico City is located (Fig. 1). Previous drilling recovered the upper $122 \mathrm{~m}$ of the sequence, whose analyses yielded stratigraphic, paleoclimatic and paleolimnological data that provided insights into the history of Lake Chalco over the past $140 \mathrm{ka}$ (Lozano-Garcia et al. 1993, 2015; Caballero and Ortega 1998; Ortega-Guerrero and Newton 1998; Torres-Rodríguez et al. 2015; Ortega-Guerrero et al. 2017, 2020; Avendaño-Villeda et al. 2018; Martínez-Abarca et al. 2019; Caballero et al. 2019). It was not until recently, however, that deep cores (520 m) were drilled in this basin (Lozano-García et al. 2017), enabling investigation into the origin of the lake.

It is widely accepted that the Basin of Mexico was an exorheic fluvial system that drained southward and whose closure occurred as a consequence of the accumulation of volcanic deposits in the south during the Pleistocene (Mooser 1963). Subsequent studies reported closure of the basin between 1300 and 600 ka (Martin del Pozzo 1982; Macias et al. 2012; 

Arce et al. 2013), determined from the age of the volcanic deposits that outcrop in the Basin today. Nevertheless, because of the inaccessibility of the oldest sediments, which are covered by younger geologic deposits, it had not been possible to explore what geological processes led to basin closure or when they occurred.

In 2016, the ICDP-supported (International Continental Scientific Drilling Program) MexiDrill Project retrieved four cores from Lake Chalco, recovering a composite sequence that extended to a maximum depth of $520 \mathrm{~m}$ (Lozano-Garcia et al. 2017; Brown et al. 2019). The initial stratigraphic description of the MexiDrill Chalco composite sequence revealed that the upper $300 \mathrm{~m}$ are composed of fine-grained lacustrine sediments, and the lower section is comprised of $>200 \mathrm{~m}$ of alluvial and fluvial deposits, as well as lavas (Brown et al. 2019; Romero-Vera 2019).

We utilized facies analysis of the deposits between 343 and 285 m depth in Lake Chalco, which record the transition from a fluvial-alluvial phase to a lacustrine phase, to infer the environmental conditions under which the lake formed and to characterize the processes that led to its development. Analysis of the formative stages of Lake Chalco is relevant to our understanding of the geologic evolution of Central Mexico and contributes information about broader questions related to lake formation in volcanically and tectonically active regions.

\section{Study area}

The Basin of Mexico, located in the east-central part of the Trans-Mexican Volcanic Belt (TMVB) $\left(19^{\circ} 15^{\prime} \mathrm{N}, 98^{\circ} 58^{\circ} \mathrm{W}\right)$, is an endorheic depression with a lacustrine plain at 2240 meters above sea level ( $\mathrm{m}$ asl). Lake Chalco is the southeastern-most water body of an ancient vast lacustrine system that developed in the Basin of Mexico during pre-Hispanic times. This 
lake system has recently undergone massive transformations and has a long history of human occupation (Niederberger 1987; Sanders et al. 1979). Today, Lake Chalco is reduced into a shallow, subsaline marsh $\left(\mathrm{Z}_{\max }<3 \mathrm{~m}\right)$, with an area of $\sim 5.5 \mathrm{~km}^{2}$, and is located next to Mexico City, a megalopolis with $>25$ million inhabitants (INEGI 2010). The current water body is the depocenter of the sub-basin of Chalco, which is morphologically delimited by the following volcanic ranges: 1) the Sierra de Las Cruces to the west, 2) Sierra de Santa Catarina to the north, 3) the Sierra Nevada to the east, and 4) the Sierra Chichinautzin Volcanic Field to the south (Fig. 1). Other volcanic structures with ages around $1300 \mathrm{ka}$ are found north of the Sierra de Santa Catarina and Jaimes-Viera et al. (2018) called them "Peñon Monogenetic Volcanic Complex (PMVG)"

The Sierra de Las Cruces is composed of lava flows, pyroclastic and lahar deposits that are aligned NW-SE (Mora-Álvarez et al. 1991). The bulk of its volcanic activity occurred during the late Miocene (Mooser et al. 1974; Osete et al. 2000). The Sierra Nevada is composed of a chain of stratovolcanoes that include: a) Tlaloc-Telapon (1.8 Ma); b) Iztaccihuatl volcanic complex (0.9-0.08 Ma); and c) Popocatepetl, whose current cone was formed 0.23 Ma ago (Nixon 1989; Macias et al. 2012; Siebe et al. 2017). At least 220 monogenetic volcanoes constitute the Sierra Chichinautzin Volcanic Field. It includes scoria cones (e.g. Xitle), shield volcanoes (e.g. Teuhtli) and lava domes (e.g. Mesa la Gloria) (Bloomfield 1975; Martin del Pozzo 1982; Marquez et al. 1999). Jaimes-Viera et al. (2018) suggested that volcanic activity in Sierra Chichinautzin occurred between ca. 1300 ka and 7 ka ago.

\section{METHODS}

Drilling, initial core description and preliminary stratigraphy 
110 The MEXI-CHA16 cores (holes 1A, 1B and 1C) were drilled near the modern lake 111 depocenter, in the sub-basin of Chalco (19 $\left.15^{\prime} 26^{\prime \prime} \mathrm{N}, 98^{\circ} 58^{\prime} 32^{\prime} \mathrm{W}\right)$ (Fig. 1C). The drilling 112 effort yielded sediment from the surface down to $520 \mathrm{~m}$ depth. Drilling was carried out using 113 a Longyear LF90 rig with standard HQ3 wireline diamond coring tools, and sediment cores 114 were retrieved in polycarbonate liners that were $1.5-\mathrm{m}$ long and $6.1 \mathrm{~cm}$ in diameter (Brown 115 et al. 2019). After completion of the field program, the sections were sent to the LacCore 116 Facility at the University of Minnesota for core measurement, scanning and description. 117 Cores were then split lengthwise, cleaned and high-resolution color scans were acquired from 118 each section using a DMT CoreScan digital linescan camera. Magnetic susceptibility was 119 measured systematically at 1-cm intervals using a Bartington MS2E sensor. Stratigraphic 120 correlation among sequences 1A, 1B and 1C was carried out by Valero-Garces et al. (In 121 press), who used magnetic susceptibility and facies identification to develop a composite 122 sequence that minimized the effects of gaps and artifacts from the drilling process.

123 Preliminary visual characterization of the MEXI-CHA16-1C core sections (color, texture, 124 structure, thickness, sorting and boundary type) were done using high-resolution images, 125 viewed with the free distribution software CoreWall (http://www.corewall.org/). Sediments analyzed for this study were between 343 and $285 \mathrm{~m}$ deep in the composite sequence.

127 Sediment description

128 Thirty-nine smear slides of samples from the MEXI-CHA16-1C core, prepared from sandy 129 to clayey materials that represent the observed major shifts in sediment texture and 130 composition, provided a basis for initial major component descriptions (Schnurrenberger et 131 al. 2003). Additionally, 21 samples of undisturbed, fine-grain (clay to sand) sediment were 
132

133

134

135

136

137

138

139

140

141

142

143

144

145

prepared for thin sections in blocks of $4 \times 5 \mathrm{~cm}$. Thin-section samples were collected in aluminum trays, freeze-dried, embedded with epoxy resin and polished to $30-\mu \mathrm{m}$ thickness in preparation for microscopic analyses. The first analysis was a petrographic micromorphological description that included general mineralogy, geometry, and microstructures, as well as documenting the presence of diatoms, charcoal and other biogenic material. The second analysis consisted of counting exclusively quartz (Q) and feldspar/plagioclase (F). Prior to counting, the thin sections were stained with potassium rhodizonate and barium chloride. Mineral phase percentages were estimated by counting 200 points, following the method of Gazzi-Dickinson (Ingersoll et al. 1984). The ratio $Q /(Q+F)$ was estimated to infer the precipitation regime under which sediment could have been deposited (Picurd 1971; Weltje 1994). According to this method, sediments having a higher $Q /(Q+F)$ ratio are indicative of wet conditions due to the loss of feldspar and plagioclase during chemical weathering (Van der Kamp 2010).

Texture analysis was carried out based on two different methods. The first one was only used for determining the grain-size distribution of coarse sand and gravel deposits, following the Rosiwal's intercepts methodology (Rosiwal 1898). This method consists on measuring clasts length intersected by parallel lines regularly spaced at $3 \mathrm{~cm}$, perpendicular to core length, on scanner images where 30 clasts (minimum) were considered without repeating the same clast thrice (Sarocchi et al. 2005). Measurements were carried out with free distribution software ImageJ (Rasband 2018). The second method, applied on clay, silt and medium/fine sand, was performed on 39 samples using a Beckman Coulter Multi-Wavelength Particle Size Analyzer. Particle sizes obtained from both methods were converted to phi units, and later, sorting was inferred by estimating standard deviation (SD) based on the grain size 
155 distribution using software $\mathrm{R}$ version 3.5.0 (R Core Team 2018). Well-sorted material has

156 SD values $>0.7$, whereas poorly sorted material has SD values $<0.7$.

157 Semi-quantitative diatom analysis was carried using the smear slide samples of fine-grained

158 (sandy to clayey) deposits. We counted diatoms in two or three parallel transects on the smear

159 slides. Diatoms were identified to genus level and at least 300 valves were counted to obtain 160 statistically significant results (Smol and Stoermer 2010). Additionally, 21 stratigraphic 161 samples were processed for pollen counting to estimate the relative percentages of the most common pollen taxa, following the Batten (1999) methodology.

163 Total nitrogen (TN), total carbon (TC) and total organic carbon (TOC) were determined on 16417 samples with a Thermo Fisher Scientific NC-Soils Analyzer FLASH 2000 Series 165 Elemental Analyzer. Total inorganic carbon (TIC) was estimated as TC-TOC. $\delta^{13} \mathrm{C}$ and $\delta^{15} \mathrm{~N}$ 166 were measured in organic matter with a DELTA PLUS Finnigan MAT Isotope Ratio Mass 167 Spectrometer at the Universidade A Coruña Laboratory (Spain). Identification of 168 aquatic/terrestrial organic matter sources was done using TN, TC, TOC and $\delta^{13} \mathrm{C}$ data, 169 following the scheme proposed by Meyers and Teranes (2001).

170 Age model

171 A preliminary Bayesian age-depth model was constructed using R studio and the Bacon 172 package (Blaauw and Christen 2011). The model took 168 sections with $3.74 \times 10^{7}$ iterations. 173 Depth data used for the model are referred to as "corrected composite depth (mcc)," which 174 considers sand and volcaniclastics to be instantaneously deposited materials. The time scale 175 for the lacustrine sequence was developed using five ${ }^{14} \mathrm{C}$ ages from the upper $36 \mathrm{~m}$ of 176 sediment, collected during earlier drilling at Chalco (core CHA08; $0.5 \mathrm{~km}$ southwest of the 
MexiDrill site in the sub-basin of Chalco) (Herrera-Hernandez 2011; Ortega-Guerrero et al. 2017) (Table 1). The ${ }^{14} \mathrm{C}$ ages were calibrated using the IntCal13 calibration curve (Reimer et al. 2013). For sediments below $36 \mathrm{~m}$ depth, a ${ }^{234} \mathrm{U} /{ }^{230} \mathrm{Th}$ date was obtained on zircons extracted from a tephra layer in a core collected previously at Chalco (core CHA08, $0.5 \mathrm{~km}$ southwest of the MexiDrill site) (Ortega-Guerrero et al. 2017). Additionally, we employed an age of $130 \mathrm{ka}$ at $106 \mathrm{~m}$ depth defined by Avendaño-Villeda et al. (2018), who identified the transition between Marine Isotopic Stages 6 and 5 based on diatoms analyses in Chalco, and assigned the age of this transition according to the Lisiecki and Raymo (2005) chronology. Finally, an age of $280 \pm 40$ ka was determined for lacustrine carbonates at $192 \mathrm{~m}$ (166.73 mcc), using ${ }^{234} \mathrm{U} /{ }^{230} \mathrm{Th}$. The latter is a tentative age that will likely be modified in future studies. It was estimated from four different sediment aliquots; one returned a date of $231 \pm 11 \mathrm{ka}$, and another returned a date of $332 \pm 14 \mathrm{ka}$ (2-sigma uncertainties). Two other aliquots returned infinite ages. We used the mean of the two finite age results to provide a rough age estimate.

\section{RESULTS}

In this section, we present facies descriptions, using the results of textural, mineralogical, compositional and stable isotope analyses from the targeted depth interval (343-285 m).

\section{Facies description}

Eight facies were defined in the sequence (Fig. 2). Using the main components, facies were grouped into three categories: 1) Detrital, which includes a) laminated silt (LS), b) massive sand (MS), c) stratified silty sand (STS), d) clast-supported gravel (CSG), and e) matrixsupported gravel (MSG) facies; 2) Biogenic, composed of a) diatom ooze (DO) and b) 
199

214 These facies are composed mainly of diatoms, pollen, charcoal, organic material, ostracods,

bivalve coquina (CO) facies; 3) Volcaniclastic, which includes clast-supported pumice (CSP) facies (Table 2).

\section{1) Detrital facies}

The detrital facies are composed of silt, sand and gravel deposits (Fig. 3). Minor components in detrital facies include biogenic remnants such as diatoms, organic material, and charcoal. Although detrital sediment is distributed along the sequence, coarser material (gravel) is more abundant toward the base of the stratigraphic column (> $315 \mathrm{~m})$. Mineralogically, sand deposits are dominated by plagioclase, feldspar, pyroxene, olivine and volcanic glass. On the other hand, gravel deposits are composed of andesite and basalt fragments. Magnetic susceptibility displays a wide range of values, with the gravel deposits showing higher values $\left(400-150010^{-5} \mathrm{SI}\right)$ than silt deposits $\left(150-25010^{-5} \mathrm{SI}\right)$. Massive sand deposits have the lowest values of total nitrogen and total organic carbon (TOC: $0.1-0.4 \%$; TN: $0.01-0.03 \%$ ), whereas laminated silt and stratified silty sand have higher values (TOC: $0.09-1.59 \%$; TN: $0.01-$ $0.09 \%)$. In addition, the massive sand sections have low values of $\mathrm{Q} /(\mathrm{Q}+\mathrm{F})$ ratio $(<0.4)$.

\section{2) Biogenic facies} gastropods and vascular plant remnants. They are present between 315 and $285 \mathrm{~m}$ depth; with the highest abundance from 306 to $286 \mathrm{~m}$ depth. Magnetic susceptibility in these deposits is between 250 and $15010^{-5} \mathrm{SI}$, the lowest in the core record. Total nitrogen varies between 0.08 and $0.52 \%$, while total organic carbon varies between 0.61 and $5.92 \%$, the highest values in the core record. There are two kinds of biogenic deposits: diatom ooze and bivalve coquina. 
221 The diatom ooze is composed of $90 \%$ diatom valves and $10 \%$ feldspar-rich silt, and other

222 components such as pollen, phytoliths, and vascular plant remains. Diatoms were divided

223 into two associations (Fig. 4F). Association A is composed of Staurosira, Rhopalodia,

224 Cocconeis, and Navicula, which correspond to shallow-water conditions. In contrast,

225 association B is formed by Stephanodiscus cf. minutulus (Kütz) Cleve \& Möller, and

226 Stephanodiscus niagarae-Ehrenberg, as well as Aulacoseira sp., which are planktonic forms

227 that are common in eutrophic and relatively deeper-water lakes (Edlund and Kingston 2004;

228 Bennion and Simpson 2011; Gabito et al. 2013). The diatom deposits are characterized by

229 high values of the $\mathrm{Q} /(\mathrm{Q}+\mathrm{F})$ ratio $(>0.4)$. Most of the diatom deposits are intercalated with 230 detrital facies, particularly between 306 and $294 \mathrm{~m}$ depth.

231 The bivalve coquina is composed of bivalve, ostracod and gastropod remnants (Fig. 4G). It 232 is present at $293 \mathrm{~m}$ depth as a unique deposit of $1.2 \mathrm{~m}$ thickness. Its palynomorph content is 233 composed mainly of the microalga Pediastrum, and pollen of Pinus, Picea, Alnus, Ambrosia 234 and Quercus.

236 Volcaniclastic facies includes four tephra deposits between 294 and $286 \mathrm{~m}$ depth (Fig. 5).

237 These are well sorted, with sub-angular pumices. Based on their color and mineralogy 238 (plagioclase, muscovite and quartz), these are from silica-rich eruptions. Magnetic 239 susceptibility has intermediate values, between 250 and $57010^{-5}$ SI. The clast-supported 240 pumice deposits are named here to represent their stratigraphic depth: a) Tephra CHA16-288, 241 b) Tephra CHA16-289a, c) Tephra CHA16-289b and d) Tephra CHA16-294. 
242 Tephra CHA16-288 is located at $288.1 \mathrm{~m}$ depth has a thickness of $13 \mathrm{~cm}$. This deposit shows

243 inverted gradation, from ash to lapilli, and has an inferior planar contact. Tephra CHA16-

$244289 \mathrm{a}$ is located at $289.6 \mathrm{~m}$ depth and is $24 \mathrm{~cm}$ thick. It is a lapilli deposit with apparent

245 lamination and an inferior planar contact. Tephra CHA16-289b is located at $289.9 \mathrm{~m}$ depth

246 and is $45 \mathrm{~cm}$ thick. It is a massive lapilli deposit with an inferior planar contact. Tephra

247 CHA16-294, located at $294 \mathrm{~m}$ depth, is $85 \mathrm{~cm}$ thick, and the largest volcanic deposit in the

248 sequence (Fig. 5H4). This deposit is divided in two units. The first, at the bottom, is

249 composed of massive lapilli with an inferior planar contact, whereas the second unit overlies

250 the first one and is a massive ash deposit with an inferior sharp contact.

251 Age model

252 The Bayesian age-depth model suggests that the upper $343 \mathrm{~m}$ of the MexiDrill Chalco 253 sequence spans the last $408 \pm 47 \mathrm{ka}$ (Fig. 6). Eighty-nine percent of the ages obtained in the 254 age-depth model are within the $95 \%$ confidence range (uncertainties $<44 \mathrm{ka}$ ). The model 255 provides a preliminary estimate for the age of the deepest lacustrine deposits in the MexiDrill 256 core. As discussed below, deposits associated with the establishment of a permanent lake are 257 at $293.1 \mathrm{~m}$ depth (236 mcc), and have a model age of $400 \pm 46 \mathrm{ka}$. The age-depth model 258 indicates that the section analyzed in this work (343-285 m; 240-229 mcc) spans $\sim 21 \mathrm{ka}$ of 259 the depositional evolution before and during the formation of Lake Chalco.

\section{DISCUSSION}

261 Formative history of Lake Chalco 
262 We divided the stratigraphic column from Lake Chalco into four phases using the 263 stratigraphy, magnetic susceptibility data, and the $\mathrm{Q} /(\mathrm{Q}+\mathrm{F})$ ratio. These stages are, from 264 deepest to shallowest: a) Alluvial, b) Fluvial, c) Transitional fluvial-lacustrine, and d) 265 Lacustrine (Fig. 2). In this section, we describe the characteristics of each stage and its 266 associated environmental processes.

Alluvial stage

268 Deposits associated with this phase are located between 343 and $330 \mathrm{~m}$ depth. They are characterized for the most part by MSG facies. The main features of this stage are the absence of organic material and high magnetic susceptibility values (Table 2). Angularity in clasts could indicate active collision between clasts during the sediment transport. Particle size is > $2 \mathrm{~cm}$, indicating high-energy transport.

273 There are two types of features in the MSG facies. The first is dominated by massive, poorly sorted and ungraded gravel, suggesting the presence of debris flows. They are gravity-driven flows of highly concentrated mixtures of sediment and water $(>80 \mathrm{wt} \%$ [percentage of total dry mass]), whose deposition occurs abruptly (Sohn et al. 1999). The second feature consists

277 of moderately sorted, usually graded gravel, with gradual coarsening upward contacts at the 278 bottom, and stratified sand at the top. These characteristics suggest the presence of hyper279 concentrated flows (Cao and Qian 1990; Cronin et al. 1999). These are gravity-driven flows, 280 but unlike debris flows, they have a suspended sand sediment content between 20 and 60 281 wt\% (Beverage and Culbertson 1964) and their deposition can generate graded deposits 282 (Pierson 2005). Presence of both hyper-concentrated and debris flow deposits leads us to 283 propose that this section corresponds to an alluvial environment (Lowe 1982; Smith 1986). 
According to our preliminary chronology, sediments in this stage may have been deposited around $408 \pm 46 \mathrm{ka}$. Additionally, presence of rock fragments rich in plagioclase, orthopyroxene, clinopyroxene and amphibole in both types of deposits suggests that the material came from ranges in the basin with basalt-andesite composition, such as the Chichinautzin, Santa Catarina, Las Cruces and Nevada ranges (Fig. 3E).

Effusive volcanic activity younger than 250 ka has been recorded in the Chichinautzin and Santa Catarina Volcanic Fields (Lugo-Hubp et al. 1994; Marquez et al. 1999; Arce et al. 2015; Ortiz-Enriquez 2017; Jaimes-Viera et al. 2018), which make them unlikely sources of the MGS deposits of the alluvial stage. Volcanic activity around the basin, which is older than $400 \mathrm{ka}$ and could have been the source of the MGS deposits, occurred in the Sierra de Las Cruces (Osete et al. 2000; Aguirre-Diaz et al. 2006; Arce et al. 2008), Peñon Monogenetic Volcanic Group (Jaimes-Viera et al. 2018) and Sierra Nevada (Nixon 1989).

\section{Fluvial stage}

CSG, MS, and STS facies constitute the fluvial stage deposits from 330 to $306.5 \mathrm{~m}$ depth. The main characteristic of this core interval is the first appearance in the record of organic materials including vascular plant remains, amorphous organic matter, and charcoal layers. These sediments, however, are devoid of remains of aquatic organisms. According to our age model, sediments of this stage are likely older than $407 \pm 46 \mathrm{ka}$.

Results of the Rosiwal method show that clasts in the CSG facies are $>2 \mathrm{~mm}$, but $<2 \mathrm{~cm}$, suggesting a high-energy transport into the water body such as a streamflow, but with lower energy than during the alluvial stage. Also, textural and compositional sediment characteristics of the CSG, such as subangular-rounded and very well sorted clastic deposits, 
in the absence of lacustrine organisms, suggest reworking (Beverage and Culbertson 1964; Smith 1986). These lithological characteristics have been recognized on the ancient lake Chalco shoreline, along with sorted sand and mud associated with recent sediments from the Amecameca River (Fig. 1B) (Frederick and Cordoba 2019). Lithological heterogeneity in CSG clasts, such as pumice, basalt, and andesite fragments, suggests that the sediment came from multiple sources (Fig. 3D). A sediment source located $>30 \mathrm{~km}$ from the drill site could significantly rework and sort the clasts. The pumice fragments present in the CSG facies (Fig. 3D1), products of silica-rich explosive volcanism, are unlikely to have come from the Sierra Chichinautzin Volcanic Field, as their products are associated more with effusive to explosive materials of basaltic to andesitic composition (Siebe et al. 2005).

SM facies are intercalated with CSG facies and the transition between the two facies is sometimes characterized by gravel deposits, which gradually are replaced by sand. This change may be associated with low-energy periods in streamflow during which fine suspended sand was deposited in standing ponds (Lespez et al. 2011; Miall 2012). Erosive contacts in the transition from sand to gravel deposits may have been associated with an increase in the streamflow energy. SM deposits show low $\% \mathrm{~N}$ and $\% \mathrm{C}$ org values (TOC: $0.1-$ 0.4\%; TN: $0.01-0.03 \%$ ), indicating low quantities of organic material, both terrestrial and aquatic (Fig. 7C).

Grain size and mineralogical analyses on STS facies show that the sedimentation pattern consists of an alternation between light quartz-plagioclase massive coarse sand layers and dark silty-sand layers rich in charcoal and plagioclase, with parallel laminations. The light layers are characterized by poorly sorted crystals and have erosive lower contacts. These characteristics may be associated with relatively short-distance transport, which precluded 
sorting of the sediment, but its energy could have eroded underlying sediments (Figs. 3C1 and $3 \mathrm{C} 2$ ). In contrast, dark layers are composed of plagioclase crystals with horizontal alignment, charcoal particles, and gradual lower contacts, suggesting settling in still waters of shallow (cm) ponds (Figs. 3C3 and 3C4). Lespez et al. (2011) described laminated silty sand with numerous charcoal and vegetal remains on thin sections similar to STS facies from a Holocene fluvial record in West Africa. Those deposits seem to be associated with periodic occurrence of fluvial inputs (floods) to a floodplain. We suggest that STS facies are associated with channel abandonment and the development of a floodplain, where light layers may represent flooding periods. Reduction of the ratio $\mathrm{Q} /(\mathrm{Q}+\mathrm{F})$ in dark-layer deposits suggests dry periods between 322 and $311 \mathrm{~m}$ depth (Van der Kamp 2010), and explains the presence of $0.5-\mathrm{cm}$ charcoal layers associated with fires in the region (Fig. 3C5). We suggest that during dark layer deposition, the floodplain level and energy declined because of dry conditions in the region.

Characteristics of the terrestrial organic matter deposited during the fluvial stage were explored using the TOC, $\delta^{13} \mathrm{C}$ and TOC/TN values. Data were divided into two groups, the first corresponding to samples from greater depths (>307 m) and the second corresponding to samples from depths $<307 \mathrm{~m}$ (Fig. 7A). Older samples have lower $\delta^{13} \mathrm{C}(-33.7$ to $-25.3 \%$ ) and TOC/TN (4.4-6.9) than younger ones ( $\delta^{13} \mathrm{C}:-23.7$ to $-19.8 \%$; TOC/TN: $\left.14.4-18.3\right)$. We would expect a post-burial diagenesis effect in the organic matter in samples under $307 \mathrm{~m}$ depth. Meyers et al. (1995) showed that selective degradation of terrestrial organic matter during post-burial diagenesis can diminish the TOC/TN ratios in sedimentary samples. The latest is associated with a selective degradation of carbon-rich sugars and lipids in plant matter buried. In this way, younger organic matter samples are generally higher in TOC/TN 
than the older ones (Hodell and Schelske 1998). In absence of post-burial processes, the $\delta^{13} \mathrm{C}$ and TOC/TN values suggest a greater input of terrestrial organic matter towards the end of this fluvial stage (Meyers and Teranes 2002) (Fig. 7A). In addition, the presence of vascular plant remains and amorphous organic matter suggest the development of soil and vegetation around the water body.

\section{Fluvial-lacustrine transition stage}

From 306.5 to 294 m depth, the facies are constituted by MS, CSG, LS, STS, DO and MSG. The principal characteristic of this stage is the novel presence of diatoms (Fig. 8). Our age model suggests that these sediments are older than $400 \pm 46 \mathrm{ka}$. This interval was divided into three sub-stages.

Sub-stage 1 (Sub1)

The first sub-stage deposits span from 306.5 to $302.8 \mathrm{~m}$ depth. The interval is characterized by a transitional fining upward contact from CGS to LS facies that suggests a decrease in the transport energy.

There are intercalations of laminated sediments of DO facies, which have high diatom content (90\%) and a minor proportion of well-sorted silt (10\%). Diatoms from association A (Staurosira, Rhopalodia and Cocconeis), are present between 306.8 and $302.8 \mathrm{~m}$ depth (Fig. 8). Several authors have observed that small species of the family Fragilariaceae, such as Staurosira, are facultative planktonic taxa that can be fast colonizers after environmental disruptions (Vos and de Wolf 1988; Gell et al. 2002; Augustinus et al. 2008). Both Cocconeis 

Sub-stage 2 (Sub2) 1997). and Rhopalodia are epiphytic forms that suggest shallow-water conditions (Gasse et al.

Multiple factors control the $\delta^{15} \mathrm{~N}$ of bulk lacustrine organic matter, such as source, depositional environment and diagenetic changes. However, an increasing number of study suggests that lower values of $\delta^{15} \mathrm{~N}$ show more intense denitrification processes and point to more oxic environments (Hollander et al. 1992; Brenner et al. 1999; Talbot and Lædak 2000; Talbot 2001; Zhong et al. 2017). The limited $\delta^{15} \mathrm{~N}$ results $\left(\delta^{15} \mathrm{~N}: 2.8-3.0 \%\right.$ ) are coherent with a relatively shallow and oligotrophic lake (Fig. 7D). Characteristics of this sub-stage indicate fluctuating conditions, but a trend from proximal littoral facies toward the formation of a shallow, oligotrophic and probable oxic lake, which we call "Paleo-Chalco-I" (Fig. 8).

Presence of a 10-cm carbonate layer (aragonite and calcite) at $303.8 \mathrm{~m}$ depth suggests that Paleo-Chalco-I became a highly concentrated shallow water body. Deposits overlying the carbonate layer (303.8-302.8 m depth) are characterized by an increase in Cocconeis and Navicula, and later rise in planktonic species characteristic of diatom association B (Stephanodiscus and Aulacoseira) (Fig. 8). This shift in diatom assemblages suggests evolution to a deeper eutrophic lake (Edlund and Kingston 2004; Bennion and Simpson 2011; Gabito et al. 2013). Additionally, TN data (0.01-0.08\%) and the TOC/TN ratio (8.0-11.2) indicate a mix of terrestrial and aquatic organic material input (Fig. 7C).

391 A second sub-stage, between 302.8 and $296.2 \mathrm{~m}$ depth, is characterized by a transitional 392 coarsening upward from the DO deposit to the CSG facies. The DO facies is dominated by 393 diatoms of association A (Staurosira and Cocconeis), which are indicative of shallow-water 
conditions, particularly between 299.3 and $298.3 \mathrm{~m}$ depth (Fig. 8). The presence of rounded and well-sorted gravel in CSG, as well as transitional changes between CSG and DO facies, indicate periodic changes in lake level and in-lake migration of littoral facies. Our $\mathrm{Q} /(\mathrm{Q}+\mathrm{F})$ data indicate wet conditions during this sub-stage. However, because of limited data resolution, we cannot correlate changes in humidity with littoral facies migration. A recent geomorphological study of abandoned Chalco shorelines revealed large sand and gravel deposits associated with river deltas during the last 7000 years (Frederick and Cordova 2019), suggesting that there is no simple correlation between climate and sedimentation. The evidence indicates that Paleo-Chalco-I had a lower lake level during sub-stage 2, and that littoral facies were deposited at the drill site, dominated by well-sorted and rounded coarse size fractions (gravels and sands), as result of wave action in the lake. During this generally low lake period, an intermittent shallow and oligotrophic lake developed.

\section{Sub-stage 3 (Sub3)}

A third sub-stage, between 296.2 and $294.0 \mathrm{~m}$ depth, is characterized by high values of magnetic susceptibility (600-1800 10-5 SI) and the presence of subangular to rounded and poorly sorted clasts, $2-10 \mathrm{~cm}$ in diameter, in the MSG facies. These characteristics suggest deposition of volcaniclastic material by debris and hyper-concentrated flows that reached the Paleo-Chalco-I, at least at the location of the drill site (Lowe 1982; Smith 1986).

\section{Lacustrine stage}

The last stage is characterized by a substantial increase in diatom content of the sediments, as well as the presence of tephra layers in the analyzed sequence and a bivalve coquina deposit. This stage is constituted by DO, CSP, CO, and LS facies. The 85-cm-thick white 
pumice deposit at $294 \mathrm{~m}$ depth, which we name "Tephra CHA16-294," is overlain by the CO

417 facies, which in turn is covered by the DO and LS facies (Fig. 5H4).

418 The thickness of CHA16-294 tephra had not previously been observed in the Chalco

419 lacustrine sequence. The thickest tephra layer $(35 \mathrm{~cm})$ recorded in the younger sediments of

420 Lake Chalco is a deposit from a Plinian eruption that occurred ca. 17 cal ka BP and came

421 from Popocatepetl (50 km from the drill site), whose major dispersion axes was in the

422 direction of Chalco (Sosa-Ceballos et al. 2012; Ortega-Guerrero et al. 2018). The source of

423 tephra CHA16-294 is unknown, but its thickness and mineralogy suggest it came from

424 eruption of nearby stratovolcanoes. Based on the estimated age for the CHA16-294 tephra

425 (400 $\pm 46 \mathrm{ka})$ and known regional volcanic activity (Table 3), we suggest that it may be

426 associated with activity in the Iztaccihuatl volcanic complex, related to the collapse of the

427 Los Pies cone (Garcia-Tenorio 2008; Macias et al. 2012). Regardless of the mechanism and

428 source that produced the CHA16-294 tephra, it is clear that the hydrographic features of the

429 basin changed as a consequence of this volcanic activity and helped establish a second

430 lacustrine phase after ca. $400 \mathrm{ka}$, which we name "Paleo-Chalco-II".

431 Above the CHA16-294 tephra (293.1 $\mathrm{m}$ depth), there is a gradual change to a unique coquina

432 deposit that is composed of bivalve, ostracod, and gastropod remains, which indicate that 433 these organisms were abundant in the lake during its initial filling (Fig. 4G). Presence of 434 gastropods and bivalves suggests that Paleo-Chalco-II was initially a carbonate-rich shallow 435 lake (Tavares et al. 2015).

436 Microalgae such as Pediastrum and Coelastrum were found at the top of the coquina facies 437 deposit (291.9 m). Pediastrum and Coelastrum have been reported as indicators of eutrophic 
conditions (Janssen and Ijzermans-Lutgerhorst 1973; Whitney and Mayle 2012; Acosta-

439 Noriega 2019). These algae suggest that after the deposition of the coquina, water level in 440 Paleo-Chalco-II rose and the water body became eutrophic. This inference is supported by 441 the $\delta^{15} \mathrm{~N}(>6.8 \%)$ and $\delta^{13} \mathrm{C}(<-25.7 \%)$ values, which suggest a deeper and more productive lake (Fig. 7D).

443

From the top of the coquina deposit $(291.9 \mathrm{~m})$ to $285 \mathrm{~m}$ depth, a significant increase in association B diatoms (Stephanosdiscus niagarae and Aulacoseira) suggests an increase in water depth (Fig. 8). Stephanodiscus niagarae is a species that was abundant in Lake Chalco during glacial stages such as Marine Isotopic Stages 2 and 6 (Avendaño-Villeda et al. 2018). This would suggest that Paleo-Chalco-II formed during a cold interval, which according to our age model, correlates with Marine Isotopic Stage 10 (374 ka) (Lisiecki and Raymo 2005). However, our chronology requires a better age control for sediments, as it is possible that the age of these deposits may be older than MIS10 even MIS12. Such old and cold periods have not yet been known in Central Mexico.

Higher diatom concentrations and TN values in Paleo-Chalco-II than Paleo-Chalco-I suggest an increase in production of aquatic organic matter as a result of large quantities of nutrients entering the water body, possibly associated with the weathering of the volcanic material from tephra CHA16-294 and subsequent ash falls (Tephras CHA16-288, CHA16-289a and CHA16-289b). Volcanic eruptions can promote changes in lacustrine systems. For instance, volcanic material in the water column could reduce available light to photosynthetic organisms, thereby lowering primary production (Barcker et al. 2000). On the other hand, input of nutrients associated with volcanic material can foster increased primary production 
460

461

462

463

464

465

466

467

468

469

470

471

472

473

474

475

476

477 Chalco-I (Fig. 9).

478

479 Lake Chalco sediments provide a unique archive of long-term record of climatic variability.

of diatoms and other algae. This effect has been documented in Lakes Alberta (Canada) and Patzcuaro (Mexico) (Hickman and Reasoner 1994; Telford et al. 2004).

Stratigraphic correlation with previous cores

Previous information regarding the stratigraphy of the lacustrine sequence and the lower rock units in the Basin of Mexico came from deep drillings at sites north of the MexiDrill location (Fig. 9; Oviedo de Leon 1967; Arce et al. 2013). At the "San Lorenzo Tezonco" core (17.6 km northwest of Chalco), lacustrine deposits were found between the surface and $70 \mathrm{~m}$ depth; in addition, microalgae such as Pediastrum and Botryococcus were encountered in several samples of lacustrine clay from 604-590 m depth, and dated to > $250 \mathrm{ka}$ (Lozano-Garcia and Sosa-Najera 2015). This was interpreted to indicate a deep and eutrophic water body. In the "Texcoco" core (24.3 km north of Chalco), lacustrine deposits were reported from $485 \mathrm{~m}$ depth to the surface; presence of clay layers with microalgae such as Botryococcus, Pediastrum and pollen of aquatic taxa as Potamogeton in several samples between 642 and $425 \mathrm{~m}$ depth, suggests the presence of an ancient water body in a wet environment (LozanoGarcia and Sosa-Najera 2015). Palynological, stratigraphic and chronological data from the San Lorenzo Tezonco and Texcoco cores suggest that a correlation exists between clay deposits reported by Lozano-Garcia and Sosa-Najera (2015), and sediments from Paleo-

\section{Chalco-I (Fig. 9)}

Regional implications

480 Our data suggest that the formation of the lake occurred ca. $400 \mathrm{ka}$ ago, which implies that 481 the drill-core sequence recovered is the longest late Quaternary lacustrine record from the 
482

483

484

485

486

487

488

489

490

491

492

493

494

495

496

497

498

499

500

501

502

503

North American tropics. The analyzed section of the MexiDrill record (343-285 m depth) allows us to study the formation of a lake in volcanic settings such as the Basin of Mexico.

Gradual changes in the sedimentary environments (alluvial and fluvial) dominated the landscape of the southern Basin of Mexico before the establishment of a lacustrine environment. Paleo-Chalco-II settlement is clearly linked to a major volcanic event, after which the lake deepened and its productivity increased. These changes in the lake could be a response to the alteration of the hydrology of the basin caused by the volcanic event. The role of volcanism in the formation of lakes has been also noted in other locations, i.e. Lake Kivu, West Africa (Pasteels et al. 1989) and Laacher See, Germany (Park and Schmincke 1997). In both cases, deposits from volcanic eruptions blocked fluvial systems and/or diverted the natural runoff in the basins.

The stratigraphy and evolution of the Basin of Mexico has been extensively studied through surficial geology and previous drill cores. Volcanic stratigraphy since the Miocene has been developed from outcrops (e.g. Enciso de la Vega 1992; Siebe et al. 2005; Jaimes-Viera et al. 2018; Arce et al. 2019), and the drill cores have provided a knowledge of the general stratigraphy of the upper 3 km (Oviedo de León 1967; Pérez-Cruz 1988; Arce et al. 2015). However, because of discontinuous sediment recovery in the drillings, as well as the lack of outcrops of fluvial and alluvial materials underlying the lacustrine deposits, the alluviallacustrine transition is for the first time reported in this work.

\section{CONCLUSIONS}

Sediment between 343 and $285 \mathrm{~m}$ depth in the MEXI-CHA16 1C core is composed of three facies groups:1) Detrital (Laminated Silt [LS], Massive Sand [MS], Stratified Silty Sand 
504 [STS], Clast-Supported Gravel [CSG], Matrix-Supported Gravel [MSG]); 2) Biogenic 505 (Diatom Ooze [DO], Coquina [CO]), and 3) Volcaniclastic (Clast-Supported Pumice [CSP]). 506 We identified four environmental stages in the deposit: 1) Alluvial (343 - $330 \mathrm{~m}$ depth), 2) 507 Fluvial (330 - $306.5 \mathrm{~m}$ depth), 3) Transitional fluvial-lacustrine (306.5 - $294 \mathrm{~m} \mathrm{depth})$, and 508 4) Lacustrine (294 - $285 \mathrm{~m}$ depth). During the alluvial stage, debris flows and hyperconcentrated flows dominated; streamflows and floodplain deposits characterized the fluvial stage; in the transitional stage, there were lacustrine and littoral deposits. Finally, volcanic 511 and lacustrine deposits dominated during the lacustrine stage. During the formation of Lake 512 Chalco, there were two lake periods: Paleo-Chalco-I, when a nutrient-poor and shallow water 513 body prevailed, and Paleo-Chalco-II, when a eutrophic and deep lake existed.

514 Formation of Paleo-Chalco-II seems to have been associated with volcanic activity, which 515 could modify the basin morphology, increased nutrient content in the lake and deposited the 516 tephra layer CHA16-294. The thickness of CHA16-294 tephra $(85 \mathrm{~cm})$ is peculiar, since this 517 is the thickest tephra known in the Chalco lacustrine sequence. It is likely that tephra CHA16518294 was the result of the collapse of Los Pies cone on the Iztaccihuatl volcanic complex.

519 However, more studies are required to test this hypothesis.

520 Our data indicates that Lake Chalco was formed during a cold interval $\sim 400 \pm 46 \mathrm{ka}$ ago, 521 which could correlate with Marine Isotopic Stage 10 (374 ka). As we refine the age control 522 for these sediments, the Chalco Basin will provide insights into global climate changes during 523 key transitions, such as between Marine Isotope Stages 10 and 9, and even Marine Isotope 524 Stages 12 and 11. 
Although the emplacement of volcanic deposits in the Basin of Mexico since Miocene, and

526 the recent depositional history at Lake Chalco (last $143 \mathrm{ka}$ ) have been widely studied, a gap

527 of information existed between the volcanic landscape and the lacustrine onset. This work is

528 a link between those scenarios and a clue in the recent evolution of the Basin of Mexico.

529 Finally, this paper provides a wide range of open questions to be explored and answered in

530 future research (e.g. refine sampling, enhance the age-depth model, describe $<285 \mathrm{~m}$ depth

531 sediments, analyze tephra deposits, etc.).

\section{ACKNOWLEDGEMENTS}

533 This work was funded by: UNAM DGAPA-PAPIIT IV100215 and IN105918, the 534 International Continental Scientific Drilling Program (ICDP Project 05-2014), the US 535 National Science Foundation (NSF-EAR1551311, NFS-EAR1803725), the CONACYT 536 National Scholarship Program (CVU/Student: 854008/629653). Special thanks to the local 537 authorities of Ejido Santiago Tulyehualco and the MexiDrill Team, who assisted with many 538 aspects of the field work. We thank the LacCore staff and others who helped with sediment 539 analyses: Susana Sosa Najera, Cecilia Caballero, Ana Ma. Soler, Sandra García León, Elena 540 Royo, Raquel López, Cinta Osácar and Jaime Díaz Ortega. Rodrigo Martínez thanks 541 UNAM's Academic Writing Program for its guidance in the preparation of this manuscript. 542 We appreciate the comments and corrections of Dr. Mark Brenner and an anonymous 543 reviewer that improved the early manuscript.

\section{REFERENCES}

Acosta-Noriega E (2019) Análisis palinológico de una secuencia lacustre de 130,000 a 103,000 años A.P. del lago de Chalco, México. Dissertation, National Autonomous University of Mexico. 
Aguirre-Díaz GJ, López-Martínez M, Rendón-Márquez G (2006) La Caldera de La Catedral, Sierra de Las Cruces, una caldera al norponiente de la Ciudad de México. Reunión Anual de la Unión Geofísica Mexicana: Puerto Vallarta, Jal., México, GEOS 26: 160-161.

Arce JL, Macías JL, Vázquez-Selem L (2003) The 10.5 ka Plinian eruption of Nevado de Toluca volcano, Mexico: Stratigraphy and hazard implications. Geological Society of America Bulletin 115(2): 230-248. $\quad$ https://doi.org/10.1130/00167606(2003)115\%3C0230:TKPEON\%3E2.0.CO;2

Arce JL, Macías R, Palomo AG, Capra L, Macías JL, Layer P, Rueda H (2008) Late Pleistocene flank collapse of Zempoala Volcano (Central Mexico) and the role of fault reactivation. Journal of $\begin{array}{lllll}\text { Volcanology and } & \text { Geothermal } & \text { 177(4): } & \text { 95earch }\end{array}$ https://doi.org/10.1016/j.jvolgeores.2008.07.015

Arce JL, Layer PW, Morales-Casique E, Benowitz JA, Rangel E, Escolero O (2013) New constraints on the subsurface geology of the Mexico City Basin: The San Lorenzo Tezonco deep well, on the basis of 40Ar/39Ar geochronology and whole-rock chemistry. Journal of Volcanology and Geothermal Research 266: 34-49. https://doi.org/10.1016/j.jvolgeores.2013.09.004

Arce JL, Layer P, Martínez I, Salinas JI, Macías-Romo MDC, Morales-Casique E, Lenhardt N (2015) Geología y estratigrafía del pozo profundo San Lorenzo Tezonco y de sus alrededores, sur de la Cuenca de México. Boletín de la Sociedad Geológica Mexicana 67(2): 123-143. Disponible en: $<$ http://www.scielo.org.mx/scielo.php?script=sci_arttext\&pid=S1405$33222015000200002 \& \operatorname{lng}=\mathrm{es} \& n \mathrm{~nm}=\mathrm{iso}>$. ISSN 1405-3322.

Arce JL, Layer PW, Macías JL, Morales-Casique E, García-Palomo A, Jiménez-Domínguez FJ, et al (2019) Geology and stratigraphy of the Mexico Basin (Mexico City), central Trans-Mexican Volcanic Belt. Journal of Maps 15(2): 320-332. https://doi.org/10.1080/17445647.2019.1593251

Augustinus P, Bleakley N, Deng Y, Shane P, Cochran U (2008) Rapid change in early Holocene environments inferred from lake Pupuke, Auckland city, New Zealand. Journal of Quaternary Science: Published for the Quaternary Research Association 23(5): 435-447. https://doi.org/10.1002/jqs.1153

Avendaño-Villeda DA, Caballero M, Ortega-Guerrero B, Lozano-García S, Brown E (2018) Condiciones ambientales a finales del Estadio Isotópico 6 (EI 6:> 130000 años) en el centro de México: caracterización de una sección de sedimentos laminados proveniente del Lago de Chalco. $\begin{array}{lllll}\text { Revista mexicana de ciencias } & \text { geológicas } & 35(2) \text { : } & \text { 168-178. }\end{array}$ http://dx.doi.org/10.22201/cgeo.20072902e.2018.2.649

Barker P, Telford R, Merdaci O, Williamson D, Taieb M, Vincens A, Gibert E (2000) The sensitivity of a Tanzanian crater lake to catastrophic tephra input and four millennia of climate change. The Holocene 10(3): 303-310. https://doi.org/10.1191\%2F095968300672848582

Batten DJ (1999) Small Palynomorphs. In: Jones TP and Rowe NP (eds) Fossil Plants and Spores: Modern techniques. The Geological Society, London: 15-19. 
Bennion H, Simpson GL (2011) The use of diatom records to establish reference conditions for UK lakes subject to eutrophication.J Paleolimnol 45:469-488. https://doi.org/10.1007/s10933$\underline{010-9422-8}$

Beverage, JP, Culbertson, JK (1964) Hyperconcentrations of suspended sediment. Journal of the hydraulics division 90(6): 117-128.

Blaauw M, Christen JA (2011) Flexible paleoclimate age-depth models using an autoregressive gamma process. Bayesian Anal 6(3): 457-474. https://doi.org/10.1214/11-BA618

Bloomfield KA (1975) Late-Quaternary monogenetic volcano field in central Mexico. Geol Rundsch 64:476-497. https://doi.org/10.1007/BF01820679

Brenner M, Whitmore TJ, Curtis JH, Hodell DA, Schelske CL (1999) Stable isotope ( $\delta 13 \mathrm{C}$ and $\delta 15 \mathrm{~N})$ signatures of sedimented organic matter as indicators of historic lake trophic state. Journal of Paleolimnology 22(2): 205-221. https://doi.org/10.1023/A:1008078222806

Brown ET, Caballero M, Cabral Cano E, Fawcett PJ, Lozano-García S, Ortega, B, et al (2019) Scientific drilling of Lake Chalco, Basin of Mexico (MexiDrill). Scientific Drilling 26. https://doi.org/10.5194/sd-7-1-2019

Caballero M, Guerrero B (1998) Lake Levels since about 40,000 Years Ago at Lake Chalco, near Mexico City. Quaternary Research 50(1): 69-79. https://doi.org/10.1006/qres.1998.1969

Caballero M, Lozano-García S, Ortega-Guerrero B, Correa-Metrio A (2019) Quantitative estimates of orbital and millennial scale climatic variability in central Mexico during the last $\sim 40,000$ years. Quaternary Science Reviews 205: 62-75. https://doi.org/10.1016/j.quascirev.2018.12.002

Cao R, Qian, S (1990) Sediment transport characteristics of hyperconcentrated flow with suspended load. In French R (ed) Hydraulics/Hydrology of Arid Lands ( $\left.\mathrm{H}^{2} \mathrm{AL}\right)$, American Society of Civil Engineers, New York, 657-662.

Cronin SJ, Neall VE, Lecointre JA, Palmer AS (1999) Dynamic interactions between lahars and stream flow: A case study from Ruapehu volcano, New Zealand. Geological Society of America Bulletin 111(1): 28-38. https://doi.org/10.1130/00167606(1999)111\%3C0028:DIBLAS\%3E2.3.CO;2

Delgado-Granados H, Cassatta W, Gisbert Pinto G, Paul R (2017) Historia geológica y eruptiva del volcán Popopocatepetl. In: Martin del Pozzo (ed) Estudios geológicos y actualización del mapa de peligros del volcán Popocatépetl, $1^{\text {st }}$ edn. Instituto de Geología, Ciudad de México, 13-17.

Edlund MB, Kingston JC (2004) Expanding sediment diatom reconstruction model to eutrophic southern Minnesota lakes. In: Heiskary S (eds) Final report to Minnesota Pollution Control Agency.CFMS Contract, Minneapolis, 32. 
Enciso-De la Vega S (1992) Propuesta de nomenclatura estratigráfica para la cuenca de México. Revista Geofísica Internacional 10(1): 26-36.

Frederick CD, Cordova CE (2019) Prehispanic and colonial landscape change and fluvial dynamics in the Chalco Region, Mexico. Geomorphology 331: 107-126. https://doi.org/10.1016/j.geomorph.2018.10.009.

Fries C (1960) Geología del Estado de Morelos y de partes adyacentes de México y Guerrero, región central meridional de México. Universidad Nacional Autonoma de México, Ciudad de México.

Gabito L, Bonilla S, Antoniales D (2013) Paleolimnological reconstruction of change in a subtropical lake: a comparison of the subfossil record to limnological data.Limnetica 32(2): 175-188. https://doi.org/10.23818/limn.32.15

García-Palomo A, Zamorano JJ, López-Miguel C, Galván-García A, Carlos-Valerio V, Ortega R, Macías JL (2008) El arreglo morfoestructural de la Sierra de Las Cruces, México central. Revista mexicana de ciencias geológicas 25(1): 158-178. Disponible en: $<$ http://www.scielo.org.mx/scielo.php?script=sci_arttext\&pid=S1026$87742008000100010 \& \operatorname{lng}=\mathrm{es} \& n r m=$ iso $>$. ISSN 2007-2902.

Garcia-Tenorio, F. (2008). Avalancha de escombros del Pleistoceno Tardío del cono de los Píes, Complejo Volcánico Iztaccíhuatl. Dissertation, ESIA TICOMAN-IPN.

García-Tovar GP, Martínez-Serrano RG (2011) Geology and geochemistry of the Pleistocene lava flows from the Telapón stratovolcano, Sierra Nevada, México. Revista mexicana de ciencias geológicas 28(2): 301-322. Recuperado de http://www.scielo.org.mx/scielo.php?script=sci arttext\&pid=S1026$87742011000200011 \& \operatorname{lng}=$ es\&tlng=en.

Gasse F, Barker P, Gell PA, Fritz SC, Chalie F (1997) Diatom-inferred salinity in palaeolakes: an indirect tracer of climate change. Quaternary Science Reviews 16(6): 547-563. https://doi.org/10.1016/S0277-3791(96)00081-9

Gell P, Sluiter IR, Fluin J (2002) Seasonal and inter-annual variations in diatom assemblages in Murray River-connected wetlands in north-west Victoria, Australia. Marine and Freshwater Research 53: 981-992. https://doi.org/10.1071/MF01021

Google Earth Pro (2020). Fecha de imagen: 01/15/2015. Maxat Technologies Images.

Hickman M, Reasoner MA (1994) Diatom responses to late Quaternary vegetation and climate change, and to deposition of two tephras in an alpine and a sub-alpine lake in Yoho National Park, British Columbia. Journal of Paleolimnology 11: 173-188. https://doi.org/10.1007/BF00686864 
Hodell DA, Schelske CL (1998) Production, sedimentation, and isotopic composition of organic matter in Lake Ontario. Limnology and Oceanography 43(2): 200-214. https://doi.org/10.4319/1o.1998.43.2.0200

654 655 656

Hollander DJ, McKenzie JA, Haven HLT (1992) A 200 year sedimentary record of progressive eutrophication in Lake Greifen (Switzerland): implications for the origin of organic-carbon-rich sediments. Geology 20(9): 825-828. https://doi.org/10.1130/00917613(1992)020\%3C0825:AYSROP\%3E2.3.CO;2

INEGI (2010) Censo de población

y vivienda. https://www.inegi.org.mx/programas/ccpv/2010/. Accessed 10 January 2020.
INEGI
(2020)
Continuo
Mexicano
de
Elevaciones; https://www.inegi.org.mx/app/geo2/elevacionesmex/. Accessed 1 September 2020

Ingersoll TF, Bullard RL, Ford JP, Grimm JD, Pickle SW, Sares (1984) The effect of grain size on detrital modes: a test of the Gazzi-Dickinson point-counting method. Journal of Sedimentary Research 54 (1): 103-116. doi: https://doi.org/10.1306/212F83B9-2B24-11D7-8648000102C1865D

Jaimes-Viera MC, Del Pozzo AM, Layer PW, Benowitz JA, Nieto-Torres A (2018) Timing the evolution of a monogenetic volcanic field: Sierra Chichinautzin, Central Mexico. Journal of Volcanology and Geothermal ${ }^{-}$Research 356: 225-242. https://doi.org/10.1016/j.jvolgeores.2018.03.013.

Janssen CR, Ijzermans-Lutgerhorst W (1973) A "local" late-glacial pollen diagram from Limburg, Netherlands. Acta Botanica Neerlandica 22: 213-220. https://doi.org/10.1111/j.1438$\underline{\text { 8677.1973.tb00835.x }}$

Lespez L, Le Drezen Y, Garnier A, Rasse M, Eichhorn B, Ozainne S, et al (2011) Highresolution fluvial records of Holocene environmental changes in the Sahel: the Yamé River at Ounjougou (Mali, West Africa). Quaternary Science Reviews 30(5-6): 737-756. https://doi.org/10.1016/j.quascirev.2010.12.021

Lisiecki LE, Raymo ME (2005) A Pliocene-Pleistocene stack of 57 globally distributed benthic $\delta^{18} \mathrm{O}$ records. Paleoceanography 20: 1003. https://doi.org/10.1029/2004PA001071.

Lowe D (1982) Sediment gravity flows: Depositional models with special reference to the deposits of high-density turbidity currents. Journal of Sedimentary Research 52(1): 279-297. https://doi.org/10.1306/212F7F31-2B24-11D7-8648000102C1865D

Lozano-García MS, Ortega-Guerrero B, Caballero-Miranda M, Urrutia-Fucugauchi J (1993) Late Pleistocene and Holocene paleoenvironments of Chalco lake, central Mexico. Quaternary Research 40(3): 332-342. https://doi.org/10.1006/qres.1993.1086 
Lozano-García S, Ortega B, Roy P, Beramendi-Orosco L, Caballero M (2015) Climatic variability in the northern sector of the American tropics since the latest MIS 3. Quaternary Research 84(2): 262-271. https://doi.org/10.1016/j.yqres.2015.07.002

Lozano-García S, Sosa-Nájera S (2015) Análisis palinológico del Cenozoico de la cuenca de México: el registro polínico de los pozos Texcoco-I y San Lorenzo Tezonco. Boletín de la Sociedad Geológica Mexicana 67(2): 245-253. Recuperado en 25 de enero de 2020, de http://www.scielo.org.mx/scielo.php?script=sci arttext\&pid=S1405$\underline{33222015000200009 \& \operatorname{lng}=\text { es\&tlng=es. }}$.

Lozano-García S, Brown ET, Ortega B, Caballero M, Werne J, Fawcett PJ, Schwalb A, ValeroGarcés BL, Schnurrenberger D, et al (2017). Deep drilling at the Chalco lake: a technical report. Boletín de la Sociedad Geológica Mexicana 69(2): 299-311. https://dx.doi.org/10.18268/bsgm2017v69n2a2

Lugo-Hubp J, Mooser F, Pérez-Vega A, Zamorano-Orozco J (1994) Geomorfologia de la sierra de Santa Catarina, México. Revista Mexicana de Ciencias Geológicas 11(1): 13-52.

Macías JL, Arce JL, García-Tenorio F, Layer PW, Rueda H, Reyes-Agustin G, López-Pizaña F, Avellán D (2012) Geology and geochronology of Tlaloc, Telapón, Iztaccíhuatl, and Popocatépetl volcanoes, Sierra Nevada, central Mexico, In: Aranda-Gómez JJ, Tolson G, Molina-Garza RS (eds) The Southern Cordillera and Beyond. Geological Society of America Field Guide 25, Mexico City, 163-193.

Márquez A, Verma SP, Anguita F, Oyarzun R, Brandle JL (1999) Tectonics and volcanism of Sierra Chichinautzin: extension at the front of the Central Trans-Mexican Volcanic belt. Journal of Volcanology and Geothermal Research 93(1-2): 125-150. https://doi.org/10.1016/S0377$\underline{0273(99) 00085-2}$

Martin del Pozzo AL (1982) Monogenetic vulcanism in sierra Chichinautzin, Mexico. Bull Volcanol 45. https://doi.org/10.1007/BF02600386

Martínez-Abarca R, Lozano-García S, Ortega-Guerrero B, Caballero-Miranda M (2019) Incendios y actividad volcánica: historia de fuego en la cuenca de México en el Pleistoceno tardío con base en registros de material carbonizado en el lago de Chalco. Revista mexicana de ciencias geológicas 36(2): 259-269. https://doi.org/10.22201/cgeo.20072902e.2019.2.1090

Meyers PA, Leenheer MJ, Bourboniere (1995) Diagenesis of vascular plant organic matter components during burial in lake sediments. Aq. Geochem 1: 35-52. https://doi.org/10.1007/BF01025230

Meyers PA, Teranes JL (2002) Sediment organic matter. In: Last WM, Smol JP (eds) and Tracking environmental change using lake sediments. Springer, Dordrech, 239-269.

Miall AD (2012) The geology of fluvial deposits: sedimentary facies, basin analysis, and petroleum geology. $4^{\text {th }}$ Edition. Springer, New York. 
Mooser F (1963). Historia tectónica de la Cuenca de México. Boletín de la Asociación Mexicana de Geólogos Petroleros 15: 239-245.

Mooser F, Nairn AE, Negendank JF (1974) Palaeomagnetic investigations of the tertiary and quaternary igneous rocks: VIII a palaeomagnetic and petrologic study of volcanics of the valley of Mexico. Geologische Rundschau 63(2): 451-483.

Mora Álvarez G, Caballero Miranda C, Urrutia Fucugauchi J, Uchiumi S (1991) Southward migration of volcanic activity in the Sierra de Las Cruces, basin of Mexico?-a preliminary K-Ar dating and palaeomagnetic study. Geofísica Internacional 30(2). http://dx.doi.org/10.22201/igeof.00167169p.1991.30.2.1134

Niederberger BC (1987) Paleopaysages et Archeologie PreUrbaine du Bassin de Mexico: Tome I. Collection D’Etudes Mesoamericaines, Mexico City.

Nixon GT (1989) The Geology of Iztaccíhuatl volcano and adjacent areas of the Sierra Nevada and Valley of Mexico. Geological Society of America Special Papers 219: 1-59.

Ortega-Guerrero B, Newton AJ (1998) Geochemical characterization of Late Pleistocene and Holocene tephra layers from the Basin of Mexico, Central Mexico. Quaternary Research 50(1): 90106. https://doi.org/10.1006/qres.1998.1975

Ortega-Guerrero B, Lozano-García S, Herrera-Hernández D, Caballero M, Beramendi-Orosco L, Bernal JP, et al (2017). Lithostratigraphy and physical properties of lacustrine sediments of the last ca. $150 \mathrm{kyr}$ from Chalco basin, central México. Journal of South American Earth Sciences 79: 507524. https://doi.org/10.1016/j.jsames.2017.09.003

Ortega-Guerrero B, García LC, Linares-López C (2018) Tephrostratigraphy of the late Quaternary record from Lake Chalco, central México. Journal of South American Earth Sciences 81: 122-140. https://doi.org/10.1016/j.jsames.2017.11.009

Ortega-Guerrero B, Avendaño D, Caballero M, Lozano-García S, Brown ET, et al (2020) Climatic control on magnetic mineralogy during the late MIS 6-Early MIS 3 in Lake Chalco, central Mexico. Quaternary Science Reviews 230: 106-163. https://doi.org/10.1016/j.quascirev.2020.106163

Ortiz-Enriquez O. (2017) Petrografía y geoquímica del vulcanismo monogenético de la Sierra de Santa Catarina, Cuenca de México. Dissertation, Autonomous University of Guerrero.

Osete ML, Ruiz-Martínez VC, Caballero C, Galindo C, Urrutia-Fucugauchi J, Tarling, DH (2000). Southward migration of continental volcanic activity in the Sierra de Las Cruces, Mexico: palaeomagnetic and radiometric evidence. Tectonophysics 318 (1-4): 201-215. https://doi.org/10.1016/S0040-1951(99)00312-1

Oviedo de León A (1967) Estudio geológico del subsuelo, basado en los datos obtenidos de la perforación del pozo profundo Texcoco No. 1. Instituto Mexicano de Petróleo, Departamento de Geología y Exploración, Ciudad de México. 
Park C, Schmincke HU (1997) Lake formation and catastrophic dam burst during the Late Pleistocene Laacher See eruption (Germany). Naturwissenschaften 84 (12): 521-525.

Pasteels P, Villeneuve M, De Paepe P, Klerkx J (1989) Timing of the volcanism of the southern Kivu province: implications for the evolution of the western branch of the East African Rift system. Earth and Planetary Science Letters 94: 353-363. https://doi.org/10.1016/0012-821X(89)90152-0

Perez-Cruz GA (1988) Estudio sismológico de reflexión del subsuelo de la Ciudad de México. Seismic reflection study of the Mexico City subsoil. Dissertation, National Autonomous University of Mexico.

Picard MD (1971) Petrographic criteria for recognition of lacustrine and fluvial sandstone, PR Spring oil-impregnated sandstone area, southeast Uinta Basin, Utah. Survey Special Studies 36: 28.

Pierson TC (1982) Transformation of water flood to debris flow following the eruptiontriggered transient-lake breakout from the crater on March 19, 1982. In: Pierson TC (ed) Hydrologic consequences of hot-rock/snowpack interactions at Mount St Helens volcano, U.S. Geological Survey, Information Services, Washington: 19-36.

Pierson TC (2005) Hyperconcentrated flow transitional process between water flow and debris flow. In: Jackob M, Hungr O (eds) Debris-flow hazards and related phenomena. Springer, Berlin, Heidelberg, 159-202.

R Core Team (2018). R: A language and environment for statistical computing. R Foundation for Statistical Computing, Vienna, Austria. https://www.R-project.org/.

Rasband WS (2018) ImageJ, U. S. National Institutes of Health, Bethesda, Maryland, USA, https://imagej.nih.gov/ij/.

Reimer PJ, Bard E, Bayliss A, Beck JW, Blackwell PG, Ramsey CB, et al (2013) IntCal13 and Marine13 radiocarbon age calibration curves 0-50,000 years cal BP. Radiocarbon 55(4): 1869-1887. https://doi.org/10.2458/azu_js_rc.55.16947

Romero-Vera C. (2019) Petrografía y geoquímica de los productos volcánicos de la base del pozo MexiDrill, cuenca de Chalco. Dissertation, National Autonomous University of Mexico.

Rosiwal A (1898) Über geometrische Gesteinsanalysen; ein einfacher Weg zur ziffermässigen Festellung des Quantitätsverhältnisses der Mineralbestandtheile gemengter Gesteine. Verhandlungen der Kaiserlich-Koeniglichen Geologischen Reichsanstalt 5/6: 143-175.

Sanders WT, Parsons JR, Santley RS (1979) The Basin of Mexico: Ecological processes in the evolution of a civilization. New York: Academic Press.

Sarocchi D, Borselli L, Macías JL (2005) Construcción de perfiles granulométricos de depósitos piroclásticos por métodos ópticos. Revista Mexicana de Ciencias Geológicas, 22(3): 371- 
382. Recuperado de http://www.scielo.org.mx/scielo.php?script=sci_arttext\&pid=S1026$87742005000300371 \& \operatorname{lng}=\mathrm{es} \& \operatorname{tlng}=$.

Schnurrenberger D, Russell J, Kelts K (2003) Classification of lacustrine sediments based on sedimentary components. Journal of Paleolimnology 29(2): 141-154. https://doi.org/10.1023/A:1023270324800

Siebe C, Arana-Salinas L, Abrams M (2005) Geology and radiocarbon ages of Tláloc, Tlacotenco, Cuauhtzin, Hijo del Cuauhtzin, Teuhtli, and Ocusacayo monogenetic volcanoes in the central part of the Sierra Chichinautzin, México. Journal of Volcanology and Geothermal Research 141 (3): 225-243. https://doi.org/10.1016/j.jvolgeores.2004.10.009

Siebe C, Salinas S, Arana-Salinas L, Macías JL, Gardner J, Bonasia R (2017) The 23,500 y 14C BP White Pumice Plinian eruption and associated debris avalanche and Tochimilco lava flow of Popocatépetl volcano, México. Journal of Volcanology and Geothermal Research 133: 66-95. http://dx.doi.org/10.1016/j.jvolgeores.2017.01.011

Smith GA (1986) Coarse-grained nonmarine volcaniclastic sediment: Terminology and depositional process. Geological Society of America Bulletin 97(1): 1-10. https://doi.org/10.1130/0016-7606(1986)97\%3C1:CNVSTA\%3E2.0.CO;2

Smol JP, Stoermer EF (2010) The diatoms: applications for the environmental and earth sciences. Cambridge University Press.

Sohn YK, Rhee CW, Kim BC (1999) Debris flow and hyperconcentrated flood-flow deposits in an alluvial fan, northwestern part of the Cretaceous Yongdong Basin, Central Korea. The Journal of Geology 107(1): 111-132. https://doi.org/10.1086/314334

Sosa-Ceballos G, Gardner JE, Siebe C, Macías JL (2012) A caldera-forming eruption 14,100 $14 \mathrm{C}$ yr BP at Popocatépetl volcano, México: Insights from eruption dynamics and magma mixing. Journal of Volcanology and Geothermal Research 213: 27-40. https://doi.org/10.1016/j.jvolgeores.2011.11.001

Talbot MR, Lærdal T (2000) The Late Pleistocene-Holocene palaeolimnology of Lake Victoria, East Africa, based upon elemental and isotopic analyses of sedimentary organic matter. Journal of Paleolimnology 23(2): 141-164. https://doi.org/10.1023/A:1008029400463

Talbot MR (2001) Nitrogen isotopes in palaeolimnology. In: Last WM, Smol JP (eds) Tracking environmental change using lake sediments. 2nd edn: physical and geochemical methods. Kluwer, Dordrecht, 401-439

Tavares AC, Borghi L, Corbett P, Nobre-Lopes J, Câmara R (2015) Facies and depositional environments for the coquinas of the Morro do Chaves Formation, Sergipe-Alagoas Basin, defined by taphonomic and compositional criteria. Brazilian Journal of Geology 45(3): 415-429. https://doi.org/10.1590/2317-488920150030211 
Telford RJ, Barker P, Metcalfe S, Newton A (2004) Lacustrine responses to tephra deposition: examples from Mexico. Quaternary Science Reviews 23(23-24): 2337-2353. https://doi.org/10.1016/j.quascirev.2004.03.014

Torres-Rodríguez E, Lozano-García S, Roy P, Ortega B, Beramendi-Orosco L, Correa-Metrio A, Caballero M (2015) Last Glacial droughts and fire regimes in the central Mexican highlands. Journal of Quaternary Science 30(1): 88-99. https://doi.org/10.1002/jqs.2761

Van de Kamp PC (2010) Arkose, subarkose, quartz sand, and associated muds derived from felsic plutonic rocks in glacial to tropical humid climates. Journal of Sedimentary Research 80(10): 895-905. https://doi.org/10.2110/jsr.2010.081

Vos PC, De Wolf H (1988) Methodological aspects of paleo-ecological diatom research in coastal areas of the Netherlands. Geologie en Mijnbouw 67(1): 31-40.

Weltje GJ (1994) Provenance and dispersal of sand-sized sediments: reconstruction of dispersal patterns and sources of sand-sized sediments by means of inverse modelling techniques. Utrecht University, Netherlands.

Whitney BS, Mayle FE (2012) Pediastrum species as potential indicators of lake-level change in tropical South America. Journal of Paleolimnology 47(4): 601-615. https://doi.org/10.1007/s10933-012-9583-8

Zhong W, Wei Z, Chen Y, Shang S, Xue J, Ouyang J, et al (2017) A 15.4-ka paleoclimate record inferred from $\delta 13 \mathrm{C}$ and $\delta 15 \mathrm{~N}$ of organic matter in sediments from the sub-alpine Daping Swamp, western Nanling Mountains, South China. Journal of Paleolimnology 57(2): 127-139. 
Fig 1 Location of Lake Chalco. A) Extent of the Transmexican Volcanic Belt (TMVB) and the Basin of Mexico. B) Basin of Mexico, the ancient lake system is indicated. C) Close view to the sub-basin of Chalco, the major ranges are indicated: a) Sierra Nevada in the east, b) Sierra de Las Cruces in the west, c) the Chichinautzin volcanic field in the south and d) Sierra de Santa Catarina to the north. Additional structures are indicated: Amecameca River and Peñon Monogenetic Volcanic Group (PMVG). D) Location of the MEXI-CHA16 core. (Geological data obtained from INEGI 2020; Satellite image from Google Earth Pro 2020).

Fig. 2 Stratigraphic column for the section between 343 and $285 \mathrm{~m}$ depth in the MEXI-CHA16-IC core. The column is composed of the facies identified at the left and the particle size at the right. The four stages proposed: a) Alluvial (385-330 m), b) Fluvial (330-306.5 m), c) Transitional Fluvial-Lacustrine (306.5-294 m), and d) Lacustrine (294-285 m). Magnetic susceptibility and moisture index $(\mathrm{Q} /(\mathrm{Q}+\mathrm{F}))$ ratio are shown, the latter calculated from thin section mineral counts

Fig. 5 Core images of volcaniclastic facies; horizontal scale in cm. H.1) Tephra CHA16-261 (MEXI-CHA16IC-172Y-1); H.2) Tephra CHA16-263a (MEXI-CHA16-IC-173Y-1); H.3) Tephra CHA16-263b (MEXI-

CHA16-IC-173Y-1); H.4) Tephra CHA16-294 (MEXI-CHA16-IC-175Y-1)

Fig. 3 Core images of detrital facies; vertical scale in cm. A) Laminated silt (MEXI-CHA16-1C-170Y-1). B) Massive sand (MEXI-CHA16-1C-189Y-1), and the different kind of clasts in this facies: B.1) Lithic type lathwortk with plagioclase phenocrysts. B.2) Pyroxene phenocrystal with high degree of weathering. B.3) plagioclase monocrystal with hacksaw twinning. B.4) Lithic microlith type in a crystalline matrix. C) Stratified silty sand (MEXI-CHA16-1C-185Y-1): C.1 and C.2) Cross-polarized and plane-polarized light microphotographs, respectively, of a light layer, plagioclase crystals are observed without alignment. C.3 and C.4) Cross-polarized and plane-polarized light microphotographs, respectively, of a dark layer; the alignment of the layers can be observed on plagioclase crystals and charcoal. C.5) Coal layer intercalated between the light layers; and C.6) chalcedony (red color) enveloping a quartz crystal. D) Clast-supported gravel (MEXICHA16-IC-189Y-1): D.1) white pumice fragments; D.2 and D.4) andesitic fragments. D.3) Calcite fragment. D.5) detrital rock fragment. E) Matrix-supported gravel (MEXI-CHA16-IC-203Y-1): E.1) Olivine (Ol), feldspar (Fd) and hornblende (Hb). E.2) Fragment of plagioclase (Pg). E.3) Fragment of augite (Aug) with high degree of weathering. E.4) Opaque minerals in a hypocrystalline matrix of plagioclase and glass.

Fig. 4 Core images of biogenic facies. Vertical scale in $\mathrm{cm}$. F) Diatom ooze (MEXI-CHA16-IC-174Y-1): F.1 and F.2) Representative diatoms from association A (Staurosira sp.); F.3, F.4 and F.5) Representative diatoms from association B (Stephanodiscus niagarae, Aulacoseira sp., and Stephanodiscus minutula, respectively). G) Coquina (MEXI-CHA16-IC-175Y-1): G.1) Gastropod; G.2) Ostracod, G.3 and G.4) Bivalve (the arrow indicates the lamellae that allowed their identification)

Fig. 6 Bayesian age-depth model for the upper $343 \mathrm{~m}$ (240 mcc) of the MEXI-CHA16-1C core. A) Parameters obtained during model development. B) Uncertainty along the sequence; 95\% confidence range is marked in a green square. C) Age-depth model; depth data correspond to the corrected composite depth that considers deposition of sand and volcaniclastic material as instantaneous events. Some specific dates referred to in this study are indicated. Additionally, stratigraphic markers are shown: Coquina (green dotted point line) and Tephra CHA16-294 (blue dotted point line). 
892 Fig. 7 A) Relation between $\delta^{13} \mathrm{C}$ and TOC/TN, illustrating the main origin of incoming organic material among the different stages of Lake Chalco. Envelopes (rectangles) for source types come from Meyers and Teranes (2001). B) Percent total organic carbon (TOC) and total nitrogen (TN) that shows the main source of organic material among the sedimentary facies. C) TN versus TOC/TN ratio that shows the main source of organic material in Paleo-Chalco-I and Paleo-Chalco-II. Arrows indicate the evolution of the paleolake. D) Relation between $\delta^{13} \mathrm{C}$ and $\delta^{15} \mathrm{~N}$ that shows limnological conditions in Paleo-Chalco-I and Paleo-Chalco-II. Arrow indicates the evolution of Paleo-Chalco-I

Fig. 8 Most abundant siliceous remnants observed in the smear slide samples. On the left is the stratigraphic column for the section between 308 and $285 \mathrm{~m}$ depth. On the right, bars of different colors indicate the representative pollen families, a range of samples without pollen content is observed. With blue dotted lines point the different sub-stages that composed the transitional stage. Orange dotted line indicates the carbonate layer location at $303.8 \mathrm{~m}$ depth. The regions on the record that correspond with Paleo-Chalco-I (blue) and Paleo-

Fig. 9 Stratigraphic correlation between the San Lorenzo Tezonco (SLT) and Texcoco (TX-1) cores (Oviedo de Leon, 1967; Arce et al. 2013) and the MexiDrill (CHA) core from Chalco (this study). Gray lines point to possible correlations between Paleo-Chalco I and II lacustrine phases and lacustrine deposits reported by Lozano-García y Sosa-Nájera (2015) in TX-1 (642 and $425 \mathrm{~m}$ depth) and SLT (between 604 and $590 \mathrm{~m}$ depth). Modified from Lozano-García and Sosa-Nájera (2015). On the right is a map showing locations of the TX-1,

913 SLT and CHA sites 